\title{
Characteristics of Pollen Grains of Different Date Pollinator Cultivars and Their Metaxenia Effect on Secondary Metabolites, Enzymes and Other Biochemical Compounds of 'piarom' Dates at Different Stages of Fruit Growth
}

Ali Reza Shahsavar ( $\nabla$ shahsava@shirazu.ac.ir)

Shiraz University

Asma Shahhosseini

Shiraz University

Research Article

Keywords: fruit growth and development, polygalacturonase, cellulase, Piarom

Posted Date: October 29th, 2021

DOI: https://doi.org/10.21203/rs.3.rs-968530/v1

License: (c) (1) This work is licensed under a Creative Commons Attribution 4.0 International License. Read Full License 


\section{Abstract}

In this study, the characteristics of pollens of eight date pollinating cultivars including 'Shahani', 'Zahedi', 'Beraem', 'Faryab', 'Sheikhali', 'Fard' and 'Jarvis' were compared and their metaxenia effects on secondary metabolites, enzymes and other biochemical compounds of 'Piarom' date fruit was investigated in four stages of fruit growth and development. The pollens of these eight pollinating cultivars were compared in terms of carbohydrate, protein starch, total phenol, flavonoids, pectin methyl esterase, and amylase enzymes. According to the results, , pollens of 'Sheikhali', 'Fard', 'Zahedi' and 'Shahani' cultivars had higher amounts of the above compounds than other cultivars. Regarding the effect of pollens on the composition of 'Piarom' date fruit, 'Fard' and 'Sheikhali' pollens produced the lowest amount of soluable tannin, which resulted in better quality of 'Piarom' date fruits. Pollens of 'Sheikhali' and 'Fard' cultivars produced the highest amounts of glucose and fructose in the fruit. In relation to sucrose, 'Jarvis' and 'Shikhali' were the best. Pollens of 'Sheikhali' and 'Fard' cultivars caused the lowest amount of chlorophyll in different stages of fruit growth, indicating better decomposition of fruit chlorophyll and, as a result, better fruit quality. Pollens of 'Sheikhali' and 'Fard' cultivars produced the highest amount of secondary metabolites such as total phenol, carotenoids and anthocyanin at different stages of 'Piarom' date fruit development. Pollens of 'Fard' and 'Sheikhali' cultivars produced the highest levels of polygalacturonase, cellulase and invertase enzymes at different stages of 'Piarom' date fruit growth. Regarding cellulase enzyme, 'Zahedi' cultivar produced more 'cellulase' in fruit than 'Sheikhali'. In general, the pollens of 'Fard' and 'Sheikhali, in comparison with other cultivars, improved the quantity and quality of 'Piarom' date fruit, due to their metaxenia properties.

\section{Introduction}

Date palm pollination by humans plays a fundamental role in the quantity and quality of products. Pollens of different date cultivars are very different in shape, size, weight, germination percentage and their constituents ${ }^{1}$ and due to their metaxenia properties, have significant effects on fruit characteristics of the same year ${ }^{2}$. Therefore, in pollination of dates, by selecting the appropriate pollen, important traits of the fruit, including its constituent compounds, can be influenced.

Date fruit is a source of secondary metabolites, such as anthocyanins, phenols, carotenoids, and flavonoids, which have protective activity against oxidative stress ${ }^{3}$. A survey of the antioxidant properties of date fruits showed that phenolic compounds, including phenolic acids and flavonoids, mainly prevent oxidative damage to lipids, nucleic acids, and proteins by inhibiting free radicals ${ }^{4}$. The antioxidant activity of date fruits is attributed to the presence of a large amount of phenolic compounds ${ }^{5}$. Phenolic compounds are reduced during the developmental stages of date fruit, reaching a minimum during the stages of maturity and ripening of the fruit ${ }^{6}$.

Date fruits undergoe significant physical and chemical changes after formation until they reache the final stage of growth. These changes include four stages, which are based on the Arabic terms kimri, khalal, Loading [MathJax]/jax/output/CommonHTML/jax.js color is green, the weight and volume of the fruit are rapidly 
increasing, the taste of the fruit is astringent, the fruit juice increases, and at the end of this stage, the fruit reaches its maximum growth. The khalal stage is accompanied by a change in the color of the fruit, which changes from green to beige,yellow, and red. The juice and weight of the fruit decreases. In the rutab stage, the color of the fruit darkens and texture softens. Astringency decreases and the amount of sugar increases. The fruit ripens and becomes edible. In the tamar stage, the fruit has the least amount of water and the highest amount of sugar. At this stage, the vital activities of the fruit are stopped ${ }^{7,8}$.

Based on a study on dates, it was stated that the khalal stage has the highest amount of phenolic, flavonoid, and tannin substances as well as antioxidant activity compared to the two stages of rutab and tamar $^{9}$. According to a study by Besbes et al. ${ }^{10}$, although the difference in the amount of total phenol in the fruits, of different date cultivars is influenced by factors such as cultivar, growth conditions, and geographical conditions, pollen grains used in pollination operations also play an important role. Chloroplasts of all higher plants have important biomarkers, including: chlorophyll a, chlorophyll b, and carotenoids, which are able to absorb effective light energy during photosynthesis ${ }^{11}$. Carotenoids, such as anthocyanins, polyphenols, and flavonoids, are low molecular weight antioxidants that play an effective role in neutralizing free radicals; that is, they protect intracellular compounds against the damaging effects of free radicals ${ }^{12}$. Chlorophyll a and carotenoids are more sensitive to stress conditions than chlorophyll $b^{13}$. Anthocyanins are the largest group of water-soluble pigments after chlorophyll, and are widely found in plants in nature ${ }^{14}$. They are an important part of plant secondary metabolites and chemically belong to the group of flavonoids with antioxidant properties ${ }^{15}$. Date fruits contain a variety of compounds, including sugars, hormones, enzymes, secondary metabolites, and antioxidant compounds that undergo many changes during different stages of date development from kimri to tamar. Considering the effect of metaxenia on date fruits and the effect of pollen characteristics on fruit composition in the same year, the need for more in-depth studies to understand the relationship between pollen type and fruit composition is necessary. The 'Piarom' date is a semi-dry and late ripening cultivar with long, elliptical fruits, approximately 3 to $5 \mathrm{~cm}$ long, brown in color with thin skin. This cultivar is known worldwide because of its high quality, and it is also a famous cultivar in Iran. If the quality of the fruit improves, it can have a significant impact on global markets. It has the highest price among the different cultivars of dates.

The aim of this study was to investigate the pollen grain compositions of eight pollinating cultivars and their metaxenia relationship with secondary metabolites, enzymes and other biochemical compounds of 'Piarom' date fruit at different stages of growth and developments.

\section{Materials And Methods}

This research was conducted in a date orchard in Jahrom city in Fars province for two consecutive years (2016-2017). In this experiment, pollens of eight pollinating cultivars including 'Sheikhali', 'Faryab', 'Beraem', 'Zahedi', and 'Kabkab' cultivars as local pollinators, and 'Jarvis' and 'Fard' cultivars as international pollinators were used for pollination of 32 (four replications; in each replication, one tree) Loading [MathJax]/jax/output/CommonHTML/jax.js 
twelve-year-old 'Piarom' date tree. Pollens were obtained from a research station located in Saadabad city of Bushehr province during ripening of male spots in March. To prevent unwanted pollination, 'Piarom' date inflorescences were covered with kraft paper before pollination. During pollination, three strands of male inflorescences were placed inside each female inflorescence and covered again with a paper bag for 4 weeks.

Measurement of pollen grain composition.

Carbohydrate and starch. To measure the amount of carbohydrates in pollens of different cultivars, $0.1 \mathrm{~g}$ of pollen was homogenized in $80 \%$ ethanol. The supernatant was then dried in an oven at $40^{\circ} \mathrm{C}$ and dissolved by adding water. The amount of soluble sugars was determined by injecting it into reversephase high-performance liquid chromatography (HPLC) (Portuguese Unicam model) with a carbohydrate column.

To measure the amount of starch, $2 \mathrm{ml}$ of hydrochloric acid was added to the remaining solution from the ethanol extract prepared for measuring carbohydrates and boiled for $30 \mathrm{~min}$. After cooling, the $\mathrm{pH}$ was reduced to 4.5 by adding potassium hydroxide to its solution. To digest the starch, 36 units of amyloglucosidase were added to the solution and kept at $50^{\circ} \mathrm{C}$ for $60 \mathrm{~min}$. Finally, the solution was kept at $25^{\circ} \mathrm{C}$ for $30 \mathrm{~min}$, and the absorption rate was read at $340 \mathrm{~nm}^{16}$.

Protein. To measure the protein, $0.05 \mathrm{~g}$ of pollen were homogenized with $2 \mathrm{ml}$ of $0.1 \mathrm{M}$ phosphate buffer with an acidity of 6.8 and centrifuged for $15 \mathrm{~min}$. Then, $50 \mu \mathrm{l}$ of the supernatant was removed and the volume was increased to $100 \mu \mathrm{l}$. Finally, $5 \mathrm{ml}$ of Bradford solution was added, and the absorbance of the solution was read at $595 \mathrm{~nm}^{17}$.

Total phenol. The amount of total phenol in pollens of different cultivars, was measured by preparing an ethanol extract of pollen grains and using the Folin-Ciocalteu reagent colorimetric method. In this method, granulated ethanol extract $(0.5 \mathrm{ml})$ was mixed with $2.5 \mathrm{ml}$ of Folin-Ciocalteu reagent (diluted 1: 10 with distilled water) and $2 \mathrm{ml}$ of $4 \%$ sodium carbonate. The solution was placed in the dark for two hours then the absorbance was measured at $740 \mathrm{~nm}$. The amount of total phenol in terms of $\mathrm{mg}$ of gallic acid per gram of plant dry weight was expressed ${ }^{18}$.

Flavonoids. To measure flavonoids in pollens of different cultivars, $0.5 \mathrm{ml}$ of ethanol extract $(4.3 \mathrm{~mol}$ of $80 \%$ ethanol) was mixed with one tenth of a milliliter of aluminum nitrate and $0.1 \mathrm{ml}$ of $1 \mathrm{M}$ potassium acetate. After $40 \mathrm{~min}$, the absorbance at $430 \mathrm{~nm}$ was measured using a spectrophotometer and the amount of total flavonoids in $\mathrm{mg}$ of quercetin per gram of dry weight of plant matter was expressed ${ }^{19}$.

Pectin methylesterase (PME). To measure the activity of PME enzyme in pollen grains of different cultivars, $50 \mathrm{mg}$ of pollens were added to $250 \mu \mathrm{l}$ of PME extraction buffer containing $0.1 \mathrm{M}$ citrate and 0.2 $\mathrm{M}$ sodium phosphate buffer and $0.1 \mathrm{M}$ sodium chloride with $\mathrm{pH} 5$ and centrifuged for 10 minutes at $14000 \mathrm{rpm}$. The supernatant was collected and one $\mathrm{ml}$ of the extract was removed, to which $0.2 \mathrm{M}$ Loading [MathJax]/jax/output/CommonHTML/jax.js 
ruthenium and $0.5 \mathrm{ml}$ of $0.6 \mathrm{M}$ calcium chloride were added to the solution and centrifuged for 15 minutes at $14000 \mathrm{rpm}$. Finally, the supernatant was collected, and the absorption rate was measured at $534 \mathrm{~nm}^{20}$.

Amylase. To measure the activity of amylase enzyme in pollen of different cultivars, pollen grains $(1 \mathrm{~g})$ were homogenized with $15 \mathrm{ml}$ of sodium citrate buffer at $\mathrm{pH} 5$. The solution was then centrifuged at $10,000 \mathrm{rpm}$ for $10 \mathrm{~min}$. The $0.5 \mathrm{ml}$ of the resulting extract was added to $3.5 \mathrm{ml}$ of hydrochloric acid solution, and the absorbance was read at $580 \mathrm{~nm}^{21}$.

Measurement of 'Piarom' date fruit compositions.

Fruit chlorophyll and carotenoid. To measure the amount of chlorophyll and carotenoids in the fruit at four stages of development (kimri, khalal, rutab, and tamar), one gram of the outer layer of fruit flesh was removed and extracted with $80 \%$ acetone and then centrifuged for 10 min. The absorbance of the supernatant at $663 \mathrm{~nm}$ (chlorophyll a), $646 \mathrm{~nm}$ (chlorophyll b), and $470 \mathrm{~nm}$ (carotenoid) was measured using a spectrophotometer. Finally, using the following formulas, the amounts of chlorophyll and carotenoids in terms of $\mathrm{mg} / \mathrm{g}$ wet weight of the sample were calculated ${ }^{22}$.

Chlorophyll a $=(19.3 \times$ A663 $-0.86 \times$ A646) V/W

Chlorophyll b $=(19.3 \times \mathrm{A} 646-3.6 \times \mathrm{A} 663) \mathrm{V} / \mathrm{W}$

Carotenoids $=100(\mathrm{~A} 470)-3.27(\mathrm{mg} \mathrm{chl} . \mathrm{a})-104(\mathrm{mg} \mathrm{chl} . \mathrm{b}) / 227$

$V=$ Volume of supernatant

$A=$ Light absorption at 663,646 , and $470 \mathrm{~nm}$

$\mathrm{W}=$ Wet weight of sample in term of gr

Fruit reducing and non-reducing sugars. To measure reducing and non-reducing sugars (glucose, fructose, and sucrose), date fruit flesh texture in tamar stage was divided into small pieces and homogenized with $100 \mathrm{ml}$ of distilled water and kept at room temperature for one hour. The resulting extract was centrifuged at $10,000 \mathrm{rpm}$ for $15 \mathrm{~min}$. Then, $500 \mu \mathrm{l}$ of the supernatant was removed and diluted with $500 \mu \mathrm{l}$ of distilled water and was increased to $4 \mathrm{ml}$ with $3 \mathrm{ml}$ of acetonitrile. The prepared solution was passed through a $0.2 \mu \mathrm{m}$ membrane filter. Glucose, fructose, and sucrose standards at concentrations of $2.5,5$, 10,15 , and $20 \mathrm{mg} / \mathrm{l}$ were also prepared. Then, $25 \mu \mathrm{l}$ of standards and extracts of date fruit were injected into the HPLC (Portuguese Unicam model) with a C18 column. Finally, the glucose, fructose, and sucrose levels were calculated ${ }^{23}$.

Fruit soluble tannin. To measure the soluble tannins, $5 \mathrm{~g}$ of fruit skin and flesh tissue in four stages of development (kimri, khalal, rutab, and tamar) were homogenized with $25 \mathrm{ml}$ of $80 \%$ methanol in a porcelain mortar and then centrifuged at $360 \mathrm{rpm}$ for $5 \mathrm{~min}$. The supernatant was separated, and the Loading [MathJax]/jax/output/CommonHTML/jax.js 
precipitate was extracted with $80 \%$ methanol and centrifuged. The supernatants were added together and made up to $100 \mathrm{ml}$ with deionized water. One milliliter of the resulting solution was mixed with $6 \mathrm{ml}$ of deionized water and half milliliter of Folin-Ciocalteu reagent (previously diluted 1: 10 with distilled water). After $3 \mathrm{~min}, 1 \mathrm{ml}$ of saturated sodium carbonate and $1.5 \mathrm{ml}$ of deionized water were added and after one hour, the amount of light absorption of the solution at $750 \mathrm{~nm}$ was read using a spectrophotometer. The concentration of soluble tannin was calculated based on the standard curve of different concentrations of pure gallic acid prepared at the same time as the samples ${ }^{24}$.

Fruit total phenol. To measure total phenol, $200 \mathrm{mg}$ of fruit skin and flesh tissue in four stages of development (kimri, khalal, rutab, and tamar) were mixed with $2 \mathrm{ml}$ of $50 \%$ ethanol in a porcelain mortar and kept for one hour. The resulting solution was centrifuged for $10 \mathrm{~min}$. Then, $200 \mu \mathrm{l}$ of the solution was mixed with $1.5 \mathrm{ml}$ of Folin-Ciocalteu reagent (diluted 1: 10 with distilled water) and kept under the same conditions for $5 \mathrm{~min}$, followed by the addition of $20 \%$ sodium carbonate $(1.5 \mathrm{ml})$. After $90 \mathrm{~min}$, the absorbance of the solution at $750 \mathrm{~nm}$ was measured using a spectrophotometer. The concentration of total phenol was calculated based on a standard curve of different concentrations of pure gallic acid ${ }^{25}$.

Fruit anthocyanin. To measure anthocyanin $0.5 \mathrm{~g}$, fruit peel in four stages of fruit development (kimri, khalal, rutab, and tamar) were homogenized with $25 \mathrm{ml}$ ethanol hydrochloric acid solution $(980 \mathrm{ml} 95 \%$ ethanol $+20 \mathrm{ml}$ concentrated hydrochloric acid). Finally, the optical density of the solution at $530 \mathrm{~nm}$ was measured using a spectrophotometer. The amount of anthocyanin was measured in mg per $100 \mathrm{~g}$ of fruit peel according to the following equation ${ }^{26}$.

Anthocyanin in $100 \mathrm{gr}$ of fruit peel $=\frac{\text { opticaldensity } \times \text { volumeofextractedsolution } \times 100}{\text { weightofthesample } \times 98.2}$

Fruit cellulase enzyme. To measure cellulase activity, $50 \mathrm{~g}$ of fruit mesocarp tissue in four stages of fruit development (kimri, khalal, rutab, and tamar) were mixed in $85 \mathrm{ml}$ of $12 \%$ polyethylene glycol and $2 \%$ sodium bisulfite for one minute. After centrifugation for $10 \mathrm{~min}$ at $10,000 \mathrm{rpm}$, the resulting material was divided into two parts to measure the enzyme activity. The resulting material was mixed with $50 \mathrm{mM}$ sodium acetate at $\mathrm{pH} 5$ and $0.5 \mathrm{M}$ sodium chloride at $4^{\circ} \mathrm{C}$ in a shaker for one hour and was centrifuged. The supernatant was separated and diluted by $5 \mathrm{mM}$ sodium acetate at $\mathrm{pH}$. By measuring the amount of reductant groups isolated from carboxymethylcellulose, cellulase activity was determined. The reaction mixture contains $0.25 \mathrm{ml}$ of pure enzyme, $0.5 \mathrm{ml}$ of $1 \%$ carboxymethylcellulose, $0.25 \mathrm{ml}$ of $100 \mathrm{mM}$ sodium acetate buffer with $\mathrm{pH} 5$ and incubated at $37^{\circ} \mathrm{C}$ for $1,2,3,4$, and $5 \mathrm{~h}$. The precursor was added to the control tubes after heat treatment, and the samples were incubated in a hot water bath for $5 \mathrm{~min}$, the amount of absorption was measured at $550 \mathrm{~nm}$. For determining the concentrations of reducing groups, the D-glucose standard was used. Cellulase activity as a unit of enzymatic activity was defined as the amount of enzyme isolated under standard conditions from one micromole of glucose per hour ${ }^{27}$.

Fruit invertase enzyme. To measure the amount of invertase enzyme in fruit at four stages of growth and development (kimri, khalal, rutab, and tamar), $5 \mathrm{~g}$ of fruit samples were homogenized in a mortar using Loading [MathJax]/jax/output/CommonHTML/jax.js tentrifuges, a dinitrosalicylic acid solution was added to form 
a color solution. Color samples were recorded using a spectrophotometer at $540 \mathrm{~nm}$, and the data were expressed in micromoles per gram of fresh material. The extraction of invertase enzyme was similar to that of cellulase. The assay mixture consists of $1.5 \mathrm{M}$ sucrose, $1 \mathrm{ml}$ enzyme extract and $0.5 \mathrm{M}$ acetate buffer ( $\mathrm{pH} 4.5)$, in a total volume of $5 \mathrm{ml}$. This mixture was incubated at $37^{\circ} \mathrm{C}$ for one hour and $1 \mathrm{ml}$ samples were taken at $10 \mathrm{~min}$ intervals during this period, and the reducing sugar was determined using dinitrosalicylic acid. The amount of reduced sugar isolated was calculated using a calibration chart, and one unit of invertase enzyme was defined as the amount of enzyme required for the hydrolysis of sucrose $(0.5 \mu \mathrm{M})$ per minute ${ }^{28}$.

Fruit polygalacturonase enzyme. To measure the polygalacturonase enzyme, fruit tissue $(2.5 \mathrm{~g})$ was homogenized in four stages of fruit development (kimri, khalal, rutab, and tamar) with a $\mathrm{pH}$ of 3 . The mixture was centrifuged for $15 \mathrm{~min}$ at $8000 \mathrm{rpm}$, and the supernatant was removed. The precipitate was washed with distilled water, and after centrifugation, the supernatant was removed. The resulting solution was mixed with $1.2 \mathrm{~mol}$ of sodium chloride in a ratio of $1: 1$ and its $\mathrm{pH}$ reached 6 , after which the supernatant was removed after centrifugation for $20 \mathrm{~min}$ at 10,000 rpm. Then, $50 \mu \mathrm{l}$ of the extract was added to $350 \mu$ l of buffer containing $0.2 \%$ polygalacturonic acid and 0.4 mol of sodium acetate with $\mathrm{pH}$ 4.4. After $10 \mathrm{~min}$ of incubation at $37^{\circ} \mathrm{C}$, the reaction was stopped with the buffer at a concentration of 0.1 mol and the $\mathrm{pH}$ equal to 9 . The amount of light absorption was measured at $276 \mathrm{~nm}$, and the enzyme activity in the samples was evaluated using a standard curve ${ }^{29}$.

Statistical analysis. This study was performed on a total of 32 twelve-years-old trees (eight treatments, four replications and one tree in each replication). A randomized complete block design was used to analyze the data. Duncan's multiple range test was used to determine the statistical significance of the means $(p<0.05)$. SPSS software was used for the data analysis.

Statement on guidelines. All experimental procedures on date palm plants comply with relevant institutional, national, and international guidelines and legislation.

\section{Results}

In this study, the results of the first and second years were not statistically different, so the average results of the two years were reported.

Pollen grain compositions. The highest amount of carbohydrates was obtained in pollens of 'Fard', 'Shahani', 'Zahedi' and 'Sheikhali' cultivars which were not significantly different from the amount of carbohydrates in pollens of 'Jarvis' cultivar. The lowest amount of carbohydrates was obtained in pollens of 'Beraem' cultivar which was not significantly different from the amount of carbohydrates in pollens of 'Kabkab' cultivar (Table 1).

The highest amount of starch was obtained in pollens of 'Fard' cultivar which was not significantly different from the amount of starch in pollens of 'Shahani' cultivar. The lowest amount of starch was 
obtained in pollens of 'Beraem' cultivar which did not show a significant difference compared to the amount of starch in pollens of 'Kabkab' and 'Faryab' cultivars (Table 1).

The highest amount of protein was obtained in pollens of 'Zahedi' cultivar which was not significantly different from the amount of protein in pollens of 'Sheikhali', 'Jarvis', 'Fard' and 'Shahani' cultivars. The lowest amount of protein was obtained in pollens of 'Kabkab' cultivar (Table 1).

The highest amount of total phenol was obtained in pollens of 'Sheikhali' and 'Fard' cultivars and the lowest amount was obtained in the pollens of 'Kabkab' cultivar, which compared to other cultivars showed a significant difference in the probability level of $5 \%$ (Table 1).

The highest amount of flavonoids was obtained in pollens of 'Shahani' and 'Zahedi' cultivars which did not differ significantly from the amount of flavonoids in pollens of 'Fard' cultivar and the lowest amount was obtained in pollens of 'Beraem' cultivar, which compared to other cultivars had a significant difference in the probability level of $5 \%$ (Table 1).

The highest amount of pectin methylesterase enzyme was obtained in pollens of 'Jarvis' cultivar which was not significantly different from the amount of this enzyme in pollens of Sheikhali cultivar and the lowest amount was obtained in the pollens of 'Beraem' and 'Kabkab' cultivars, which had a significant difference in the level of $5 \%$ probability compared to other cultivars (Table 1 ).

The highest amount of amylase enzyme activity was obtained in pollens of 'Zahedi' cultivar which was not significantly different from the amount of this enzyme in pollens of Sheikhali cultivar and the lowest amount was obtained in pollens of 'Faryab' and 'Kabkab' cultivars, which was significantly different from other cultivars at a probability level of $5 \%$ (Table 1 ).

Fruit compositions.

Fruit total phenol. The highest amount of total phenol of 'Piarom' date fruit in kimri stage was obtained by pollens of 'Jarvis' and 'Shahani' cultivars and the lowest amount was obtained by pollens of 'Kabkab' cultivar which had a significant difference in $5 \%$ probability level compared to other cultivars (Table 2). During the khalal stage, the highest amount of total phenol was observed with pollens of 'Jarvis', 'Shahani' and 'Sheikhali' cultivars and the lowest amount with pollens of 'Kabkab' and 'Beraem', which was significantly different from other cultivars at a probability level of $5 \%$. Also, in rutab stage, the highest amount of total fruit phenol with pollens of 'Jarvis' and 'Shahani' cultivars and the lowest amount was created with pollens of 'Kabkab' and 'Beraem' and In tamar stage, the highest amount of total phenol was produced with pollens of 'Jarvis' and 'Shahani' cultivars and the lowest amount was produced with pollens of 'Kabkab' and 'Beraem' which had a significant difference in 5\% probability level compared to 'Shahani' and 'Jarvis' cultivars. Therefore, after pollination with all pollinating cultivars, the amount of phenol of 'Piarom' date fruit decreased significantly from the kimri to tamar stage (Table 2).

Fruit soluble tannin. The highest amount of 'Piarom' palm fruit tannin was produced in the kimri stage Loading [MathJax]/jax/output/CommonHTML/jax.js s which had no significant difference in the amount of fruit 
tannin with the pollens of 'Beraem' and 'Faryab' cultivars at $5 \%$ probability level (Table 3). Also, the lowest amount was observed in this stage with pollens of 'Fard', 'Sheikhali' and 'Zahedi' cultivars. During the khalal stage, the highest amount of fruit tannin was obtained with pollens of 'Kabkab', 'Beraem' and 'Faryab' cultivars, which did not differ significantly from the amount of fruit tannin with 'Jarvis' pollens at $5 \%$ probability level. The lowest amount of tannin was observed in this stage with pollens of 'Fard' cultivar. In the rutab stage, the highest amount of fruit tannin was obtained with pollens of 'Kabkab', 'Beraem', 'Faryab' and 'Jarvis' cultivars and the lowest amount was obtained with pollens of 'Fard', 'Sheikhali', 'Zahedi' and 'Shahani' cultivars which had a significant difference with other cultivars in the probability level of $5 \%$. In tamar stage, the highest amount of tannin was obtained with pollens of 'Kabkab' and 'Beraem' cultivars and the lowest amount was obtained with pollens of 'Fard', 'Sheikhali' and 'Zahedi' Which had a significant difference with other cultivars in the probability level of $5 \%$.

Fruit chlorophyll $a$ and $b$. Most of the chlorophyll a content of 'Piarom' date fruit in kimri stage was observed with pollens of 'Jarvis' and 'Shahani', in khalal stage with pollens of 'Jarvis'and in rutab and tamar stages with pollens of 'Jarvis' and 'kabkab cultivars (Table 4). The lowest amount of chlorophyll a in the kimri stage was obtained with pollens of 'Beraem' and 'Faryab', in the khalal stage with pollens of 'Fard', 'Sheikhali' and 'Zahedi' and in the rutab and tamar stages with pollens of 'Fard' cultivar.

The highest amount of chlorophyll $b$ of 'Piarom' date fruit was obtained in kimri stage with pollens of 'Jarvis' and 'Shahani', in khalal stage with pollens of 'Jarvis', in rutb stage with pollens of 'Jarvis', 'Kabkab' and 'Beraem' and in tamar stage with pollens of 'Jarvis' and kabkab cultivars. Least amount of chlorophyll b of 'Piarom' date fruit was obtained in kimri stage with pollens of 'Beraem' and 'Faryab', and in khalal, rutab and tamar stages with pollens of 'Fard' and 'Sheikhali' cultivars (Table 5).

Fruit carotenoid. The highest amount of carotenoid of 'Piarom' date fruit after pollination with pollens of eight cultivars was observed in kimri stage with pollens of 'Fard' and 'Sheikhali', in khalal stage with pollens of 'Fard', in rutab stage with pollens of 'Fard' and 'Sheikhali' and in tamar stage with pollens of 'Fard' cultivar (Table 6). Also, the lowest amount of carotenoids of 'Piarom' date fruit was obtained in the kimri stage with pollens of 'Kabkab', Beraem' and 'Faryab', in khalal stage with pollens of 'Kabkab', 'Beraem', 'Faryab' and 'Jarvis', in rutab stage with pollens of 'Kabkab' and in tamar stage with pollens of 'Kabkab' and 'Beraem' cultivars. In general, the amount of carotenoids in 'Piarom' date fruit increased after pollination with pollens of eight pollinating cultivars from kimri to khalal stage and decreased in the rutab, and tamar stage. The highest amount of carotenoids with pollen of all studied cultivars was observed in the khalal stage, which is the coloring stage of date fruit growth (Table 6).

Fruit anthocyanin. The highest amount of anthocyanin in date fruit of 'Piarom' date cultivar after pollination with pollens of eight pollinating cultivars was obtained in kimri, khalal, rutab, and tamar stages with pollens of 'Shahani', 'Sheikhali', 'Zahedi', 'Fard', 'Jarvis' and 'Faryab' respectively (Table 7).

The lowest amount of anthocyanin was obtained in kimri, khalal, rutab, and tamar stages with pollens of 'kabkab' and 'Beraem'cultivars. 
Fruit reducing and non-reducing sugars. The highest amount of glucose in 'Piarom' date fruit in tamar stage was observed after pollination with pollens of 'Sheikhali', 'Fard' and 'Zahedi' and the lowest amount was observed with pollens of 'Kabkab' and 'Beraem' cultivars, which showed a significant difference with other cultivars in the probability level of $5 \%$ (Table 8). The highest amount of fructose sugar of 'Piarom' date fruit was produced in tamar stage after pollination with pollens of 'Sheikhali' and 'Fard' cultivars, which was not significantly different from the amount of fruit fructose with pollens of 'Zahedi' cultivar and the lowest amount was observed with pollens of 'Kabkab' and 'Beraem' cultivars, which showed a significant difference in the level of $5 \%$ probability compared to other cultivars (Table 8 ). The highest amount of sucrose sugar of 'Piarom' date fruit in tamar stage was observed after pollination with pollens of 'Jarvis' cultivar and the lowest amount was observed with pollens of 'Kabkab' cultivar which showed a significant difference in the probability level of $5 \%$ compared to other cultivars (Table 8 ).

Fruit polygalacturonase enzyme. The highest activity of polygalacturonase enzyme of 'Piarom' date fruit after pollination with pollens of eight pollinating cultivars in the kimri stage was observed with pollens of 'Fard', 'Sheikhali', 'Zahedi' and 'Shahani' and in khalal, rutab and tamar stages with pollens of 'Fard' cultivar which showed a significant difference with other cultivars in the probability level of $5 \%$ (Table 9). In addition, the lowest amount was created in the kimri, khalal, rutab, and tamar stages with pollens of 'Kabkab' and 'Beraem' cultivars, respectively, which showed a significant difference in the level of $5 \%$ probability compared to other cultivars.

Fruit cellulase enzyme. The highest activity of cellulase enzyme of 'Piarom' date fruit after pollination with pollens of eight pollinating cultivars in kimri stage was obtained with pollens of 'Fard' and 'Zahedi', in khalal and rutab with pollens of 'Fard' and in tamar stage with pollens of 'Fard' and 'Zahedi' cultivars (Table 10). The lowest activity of cellulase enzyme was obtained in kimri, khalal, rutab, and tamar stages with pollens of 'Beraem' cultivar.

Fruit invertase enzyme. The highest invertase enzyme activity of 'Piarom' date fruit after pollination with pollens of eight pollinating cultivars in the kimri stage was observed with pollens of 'Sheikhali' and 'Fard', in khalal stage with pollens of 'Sheikhali', in rutab stage with pollens of 'Sheikhali' and 'Fard' and in tamar stage with pollens of 'Sheikhali' which compared to the amount of this enzyme with pollens of 'Fard' cultivar did not show a significant difference in the level of $5 \%$ probability (Table 11). The lowest amount in kimri stage was observed with pollens of 'Kabkab', in khalal stage with pollens of 'Kabkab' and 'Beraem', in rutab stage with pollens of 'Kabkab' and in tamar stage with pollens of 'Kabkab', 'Beraem' and 'Faryab' cultivars which compared to the cultivars that had the highest amount of invertase enzyme in different stages of kimri, khalal, and tamar showed a significant difference in the level of $5 \%$ probability.

\section{Discussion}

Pollen grains characteristics. According to the results, the pollen of different cultivars had different amounts of carbohydrates. This can be due to differences in genetic structure and growth conditions, especiallv the aae and arowth nower of the plants that produce them. The most important carbohydrates Loading [MathJax]/jax/output/CommonHTML/jax.js

Page 10/32 
in pollen are sucrose, glucose, and fructose. Simple sugars are used as a source of energy to germinate pollen. Carbohydrates are important compounds for the growth and development of pollens. Impaired sugar metabolism in anthers leads to harmful effects on pollen and eventually causes sterility ${ }^{30}$. In this study, pollens of cultivars that contain higher amounts of carbohydrates, also have desirable and better conditions for fertilization and fertility of female organs of 'Piarom' date trees and subsequently produce high quality fruits.

Starch is a glucose polymer. In the anther of the flower stamen, starch is considered the most important sugar storage for microsporangium. Decomposition of starch according to the type of plant species occurs during microsporogenesis and after or regularly during the growth and development of pollen ${ }^{31}$. Therefore, decomposition of starch in pollen grains can provide the necessary sugars for pollens germination and fertilization processes ${ }^{32}$. In our study, differences in the amount of starch in pollens of different date pollinator cultivars may be due to differences in genetic structure, and plant growth conditions. On the other hand, due to the fact that the starch reserves in pollens are considered as a source of energy for pollen germination and pollen tube growth, cultivars such as 'Fard' and 'Shahani' with large amounts of starch can cause better fertilization and fertility of 'Piarom' trees.

Protein and starch in pollen are considered primary sources of energy for pollen grain germination and pollen tube growth ${ }^{33}$. Small pollen grains contain more protein, and large pollen grains have more starch, both of which are effective in pollen tube growth ${ }^{34}$. Species whose pollen is high in protein have high and rapid pollen tube growth and species whose pollen is low in protein have low pollen tube growth ${ }^{35}$. Proteins and lipids in pollen exine can affect the rate of pollen tube growth in egg cells ${ }^{34}$. In this study, the presence of different amounts of proteins in the pollen could also be due to genetic conditions along with different growth and developmental conditions of plants producing them. The pollens of cultivars which contain higher amounts of protein due to the role of proteins in the process of adhesion of pollens to stigma surface cells, have more effective interaction with the flowers pistil of 'Piarom' date trees after pollination.

Pollens and date fruits have antioxidant properties due to their phenolic compounds, flavonoids, carotenoids and anthocyanin ${ }^{36}$. In plants, these compounds protect plant cells against oxidative stress caused by free radicals ${ }^{37}$. Phenolic compounds are one of the most important compounds that exhibit antioxidant activity in pollens. Flavonoids are also the largest group of phenolic compounds in nature and are found in free or glycoside forms ${ }^{38}$. Flavonoids are plant secondary metabolites of polyphenols derived from the phenylpropanoid pathway and are a group of antioxidants ${ }^{39}$. Flavonoids are produced in the pollen of tapetum tissue. Biosynthesis of these compounds is essential for the normal growth of pollen. The mutant plants, which were unable to synthesize flavonoids, produced sterile male plants with white pollen. In addition, pollen without flavonoids does not grow well ${ }^{40}$. In this study, the difference in the amount of phenolic substances and flavonoids in the pollen of different cultivars of date palm pollinators is due to differences in genetic structure conditions and the growth and development of plants producing 
them. Pollens of cultivars that contain higher amounts of these compounds have desirable quality characteristics for the process of fertilization and fertility of 'Piarom' date trees.

The cell wall at the end of the pollen tube is mainly composed of methyl-esterified pectins which are responsible for the high flexibility of the pollen tube tip as well as the possibility of expanding and developing $i t^{41}$. The pectin methyl esterase enzyme is a protein derived from the endoplasmic reticulum, which plays a major role in causing significant changes in the cell wall of the pollen tube. This enzyme also plays a major role in the formation of cell walls in plants ${ }^{42}$.

Pollens are considered physiological systems. The growth and germination of pollen on the stigma of female organs are affected by environmental conditions such as temperature, water content, UV rays, and food reserves. Nutrient reserves in pollen are used during pollen tube growth and germination. Therefore, enzymes must be present to digest the nutrient stores in the pollen as well as to decompose the surrounding pectin membrane ${ }^{43}$. The amylase enzyme breaks down starch particles into glucose for consumption and absorption. Starch is a major source of carbon and a major source of carbohydrates ${ }^{44}$. In this study, differences in pectin methylesterase and alpha-amylase enzymes in pollens of different date pollinator cultivars can be caused by differences in the genetic origin and growth conditions of the plants that produce them. Pollens of cultivars that contain large amounts of pectin methyl esterase enzyme can promote effective longitudinal growth of pollen tubes. In addition, pollens of cultivars that contain higher amounts of alpha-amylase can effectively break down the starch reserves in pollens to facilitate proper longitudinal growth of the pollen tube. Therefore, the use of such pollens during pollination on 'Piarom' palm trees can lead to effective fertilization and fertility, followed by the production of high-quality fruits.

Fruit characteristics. In this study, pollination with pollen from all eight pollinating cultivars produced the highest amount of phenolic compounds in the kimri stage and gradually, with the progress in the khalal, rutab, and tamar stages decreased, reaching the lowest level in the tamar stage. A decrease in the amount of phenolic compounds with progress in the growth and development of date fruits has also been observed in date cultivars of the United States, Saudi Arabia ${ }^{45}$ and Tunisia ${ }^{9}$. Amira et al ${ }^{9}$. showed that the khalal stage had the highest amount of phenolic compounds compared to the rutab and tamar stages. In a study on several date cultivars, it was observed that the amount of phenolic compounds in fruit flesh was reduced by $25 \%$ from the khalal to tamar stage ${ }^{46}$. According to Al-Turki et al. ${ }^{45}$, the amount of phenolic compounds in date fruits varies between different cultivars and different stages of fruit development. The reduction of phenolic compounds in date fruits from the khalal to tamar stage has been reported because of the oxidation of these compounds by polyphenol oxidase enzyme ${ }^{47}$, as well as decreases in soluble tannins ${ }^{48}$.

In our study, pollen grains of 'Jarvis' and 'Shahani' cultivars, which lead to the production of higher amounts of phenolic compounds in the fruit, have desirable characteristics and compatible with 'Piarom' date trees which can lead to the production of fruits with favorable metabolic conditions. The presence of small amounts of phenolic compounds in the fruits of 'Piarom' dates caused by pollens of 'Kabkab' and 
'Beraem' cultivars $\square$ can be due to reduced quality characteristics and less compatibility in pollen grains of these cultivars.

Changes in tannin compounds during the development of date fruits play a decisive role in the usability of date fruits during the khalal or later stages of fruit development ${ }^{46}$. According to previous studies ${ }^{49,50}$, the use of pollen from different pollinators during the date pollination process leads to the production of different amounts of tannins at different stages of fruit development. However, the amount of fruit tannin under pollination with different pollinators decreased from kimri to khalal, rutab, and tamar. Tannins can form reversible bonds with polysaccharides, proteins, and alkaloids owing to their hydroxyl groups ${ }^{46}$. The balance between soluble and insoluble tannins plays an important role in determining the ability of dates to eat, so high concentrations of tannins may make dates inedible ${ }^{51}$. In our study, it was observed that the use of pollen from different date pollinator cultivars led to changes in fruit tannin levels during different stages of growth and development of 'Piarom' date fruit. After pollination by pollen from all eight pollinating cultivars, the amount of tannin in the fruit decreased from the kimri-to-tamar stage. Also, pollens of 'Fard' and 'Sheikhali' cultivars led to the production of the lowest amounts of fruit tannin in most stages of growth and development of 'Piarom' date fruit. In contrast, 'Kabkab' and 'Beraem' cultivars produced the highest amount of fruit tannin in most of these stages. This condition can be due to favorable quality conditions and more compatibility of pollens of 'Fard' and 'Sheikhali' cultivars with 'Piarom' date trees and production of fruits with better growth and metabolic conditions, which may be mainly due to the production of higher amounts of hormones in them. Finally, with the pollens of 'Fard' and 'Sheikhali' cultivars, fruits with the least amount of tannins are produced, which is a desirable biochemical property.

Pollination of 'Piarom' palm trees with pollens of eight pollinating cultivars resulted in different amounts of chlorophyll $a$ and $b$ at different stages of fruit development. The highest amount of chlorophyll $a$ and $b$ of 'Piarom' date fruit was observed after pollination with pollens of all eight pollinator cultivars in the kimri stage and the lowest amount was observed in the tamar stage. This process is due to the enzymatic degradation of chlorophyll during the ripening stage of the fruit. It was also observed that pollens of 'Jarvis' and 'Kabkab' cultivars, which lead to higher chlorophyll production in 'Piarom' date fruit, also had late ripening fruits. On the other hand, pollens of 'Fard' and 'Sheikhali' cultivars, which resulted in lower chlorophyll content in 'Piarom' date fruit, produced early ripening fruits. Therefore, it seems that the pollens of 'Fard' and 'Sheikhali' cultivars, by producing optimal amounts of chlorophyllase enzyme, were able to degrade chlorophyll in a shorter period of time than other cultivars. Early in the development of the fruit, the chlorophyllase enzyme binds to the inner membrane of the chloroplast and thus does not have access to the chlorophylls in the thylakoids. During the maturation and aging process of a fruit or leaf, chloroplast continuity is lost and the chlorophyllase enzyme is in direct contact with chlorophyll, which eventually causes its decomposition ${ }^{52}$. In a study on 'Zaghloul' date cultivar ${ }^{53}$, it was reported that the use of pollens of different cultivars during pollination leads to changes in the amount of chlorophyll a and $b$ of the fruit during different stages of growth and development. In addition, in fruits produced by all pollinators, a sianificant decrease in chlorophyll $a$ and $b$ was observed from the kimri stage to the khalal. Loading [MathJax]/jax/output/CommonHTML/jax.js 
On the other hand, non-pollinated fruits had higher levels of chlorophyll $a$ and $b$ at different stages of fruit development compared to pollinated fruits. These results were consistent with those of the present study.

Carotenoids such as anthocyanins, polyphenols and flavonoids are low molecular weight antioxidant compounds that have an effective role in neutralizing free radicals, leading to the protection of intracellular compounds against the damaging effects of free radicals ${ }^{12}$. Carotenoids have been reported to be rapidly reduced in ripe dates, and anthocyanins are found only on fresh dates ${ }^{54}$. In addition, through the growth and development of plant tissues towards maturation and aging, compounds such as pigments, proteins, and phospholipids are reduced, which may be due to their decomposition by free radicals; at this stage of development, the plant protection system is reduced to neutralize free radicals ${ }^{55}$. According to a study, the amount of carotenoids is high during the early growth and development of date fruits and then decreases during fruit ripening ${ }^{56}$. Under environmental stresses that lead to the production of different types of reactive oxygen species in plant cell chloroplasts, the presence of carotenoids protects photosynthetic tissues and chlorophylls ${ }^{57,58}$. In the present study, pollens of 'Fard' and 'Sheikhali' cultivars led to the production of the highest amount of carotenoids in 'Piarom' date fruit. Therefore, it seems that the pollens of these cultivars, due to their favorable morphological and physiological characteristics, and also, more compatibility with 'Piarom' palm trees, have led to the production of fruits with desirable quantitative and qualitative characteristics such as the presence of increased amounts of carotenoids. On the other hand, the presence of the highest amount of carotenoids in the khalal stage can be due to the major decomposition of chlorophyll in this stage, which leads to the appearance of carotenoids produced in the fruit. Carotenoids were produced in the early stages of date palm growth in the kimri stage, but due to the presence of large amounts of chlorophyll a and b, they did not have the opportunity to appear. In other words, carotenoids are hidden in the chlorophyll coating .

The amount of anthocyanin in 'Piarom' date fruit after pollination with pollens of eight pollinating cultivars increased from the kimri stage to the khalal, in a way that in the khalal stage it has more amount and from this stage to the rutab and tamar stages decreased. Also, different levels of anthocyanin were produced in 'Piarom' date fruit after pollination with pollens of different pollinating cultivars, which shows the effect of pollen grain metaxenia effect on the characteristics of 'Piarom' date fruit. Because there are sugar units in the molecular structure of anthocyanin, the production of these pigments depends on the presence of sunlight and the amount of carbohydrates in the plant ${ }^{59}$. In our study, pollens, which led to the synthesis of more sugars in 'Piarom' fruit, also produced higher levels of anthocyanin in the fruit. In a study to investigate the characteristics of 'Zaghloul' date fruit under the influence of different pollinators, it was reported that pollens from different pollinators lead to changes in the amount of anthocyanin in date fruit during different stages of fruit development. In this study, the anthocyanin content increased with the developmental stage of the date fruit. In addition, the pollen of these pollinators produced the highest amount of fruit anthocyanin in the khalal stage ${ }^{53}$, which is consistent with the results of our study. 
In the present study, the use of pollens of different cultivars led to the production of different amounts of glucose fructose and sucrose in 'Piarom' date fruits. This trend may indicate the effect of pollen grain metaxenia effect on the activity of invertase enzyme to break down sucrose into glucose and fructose. The pollens of 'Sheikhali', 'Fard' and 'Zahedi' cultivars in comparison with the pollens of 'Kabkab' and 'Beraem' led to the highest levels of glucose and fructose in 'Piarom' date fruits. Carbohydrates in date fruits mainly contain reducing sugars such as glucose, maltose and non-reducing sugars such as sucrose and small amounts of polysaccharides such as cellulose and starch ${ }^{36}$. The amount of reducing sugars in date fruits is considered an important criterion for determining their quality. Glucose and fructose reducing sugars have the highest sugar content in most date cultivars ${ }^{60}$. In all date cultivars, the amount of sugars increases during fruit development and reaches its maximum at the end of fruit maturity ${ }^{61}$. One study reported that date fruit sugar can be affected by different pollinator sources during pollination. In 'Hayany' cultivar, the highest amount of total sugar and reduced sugar was obtained with pollens of M1 cultivar ${ }^{62}$. In addition, date fruits pollinated with pollen from different pollinating cultivars have more reduced sugars and non-reduced and total sugar compared to non-pollinated fruits ${ }^{50}$.

In general, the activity of polygalacturonase and cellulase enzymes in date fruits increases from the initial stages of fruit development to the stages of maturity and fruit ripening. The process of softening fruit tissue during the ripening stage by cell wall expanding proteins, increases the activity of enzymes such as polygalacturonase and cellulase in the cell wall. Different date cultivars have very low levels of polygalacturonase in the green stage of the fruit. The major increase in the activity of this enzyme occurs when the date fruit changes from green to yellow or other colors depending on the variety (khalal stage). Therefore, an increase in the activity of this enzyme in date fruits occurs, especially in the final stages of fruit ripening, leading to a rapid decrease in fruit firmness ${ }^{63}$. In this study, using pollen from different date pollinator cultivars led to the production of different amounts of polygalacturonase activity at different stages of growth and development of the date fruit. This could be due to the metaxenia effect of pollen grains of different cultivars on the activity of the polygalacturonase enzyme. Pollens of 'Fard' cultivar produced the highest amount of polygalacturonase activity in most stages of growth and development of 'Piarom' date fruit. Therefore, it seems that the pollens of 'Fard' cultivar have more favorable physiological conditions and more compatibility with 'Piarom' palm trees compared to 'Kabkab' and 'Beraem' cultivars. The pollens of 'Fard' cultivar leads to the production of fruits with high activity of polygalacturonase enzyme to decompose pectin compounds and soften fruit tissue during the stages of maturity and fruit ripening.

The enzyme cellulase is present in the fruit of all plant species, and together with the enzyme polygalacturonase, plays an important role in the process of softening the fruit during the ripening stage ${ }^{64}$. According to a study on 'Lonet Mesaed' dates, cellulase enzyme activity is relatively low in the early stages of date fruit development then its activity is greatly increased so that it reaches its maximum in the khalal stage and decreases slightly in the rutab stage ${ }^{65}$. In our study, the use of pollens of different date pollinator cultivars led to the production of different amounts of cellulase enzyme activity at Loading [MathJax]/jax/output/CommonHTML/jax.js of 'Piarom' dates. This trend can be attributed to the

Page $15 / 32$ 
metaxenia effect of the pollen of different cultivars on cellulase enzyme activity. Pollens of 'Fard' and 'Zahedi' cultivars in comparison with pollens of 'Beraem' cultivar led to the production of fruits with the highest levels of cellulase activity in 'Piarom' date fruit which indicates that these pollinators are more compatible with 'Piarom' trees.

Softening of fruit tissue during the fruit ripening process, in addition to the amount of moisture, also depends on the activity of a number of hydrolyzing enzymes such as invertase ${ }^{66}$. Invertase enzymes convert sucrose to reducing sugars (glucose and fructose). The highest amount of invertase enzyme was observed during the ripening stage of date fruits (khalal). Invertase activity is higher in soft date cultivars than in semi-dry dates ${ }^{63}$. Invertase enzyme activity in 'Hillawi' cultivar showed that this enzyme is not active in the early stages of date fruit development. However, the highest level of activity was observed in the fruit ripening stage (khalal), and the lowest level of activity was observed in the tamar stage ${ }^{67}$. In general, the highest invertase enzyme activity was observed in different date cultivars during the khalal stage and decreased during the rutab and tamar stages ${ }^{63}$. In a study on 'Shahani' and 'Piarom' cultivars, it was reported that the amount of invertase enzyme increased sharply from the kimri to khalal stage and then decreased in the rutab and tamar stages ${ }^{68}$. In the present study, the use of pollens of different date pollinator cultivars led to the production of different amounts of invertase enzyme activity during different stages of growth and development of 'Piarom' date fruit. This condition can be due to the metaxenia effect of pollen grains of different cultivars on the level of invertase activity in 'Piarom' date fruit. In this study, the activity of invertase enzyme in 'Piarom' date fruit increased after pollination with pollens of eight pollinating cultivars from kimri to khalal stage and then decreased in rutab and tamar stages. Also, pollens of 'Sheikhali' and 'Fard' cultivars in comparison with pollens of 'Kabkab' and 'Beraem' cultivars led to the highest amount of invertase activity in different stages of fruit growth which shows the desirable quality characteristics and greater compatibility of these pollinators with 'Piarom' date trees.

\section{Conclusion}

Different date pollinator cultivars have pollen with different constituents and characteristics due to their genetic origin and different growth and developmental conditions. In this study, the eight pollinators differed in carbohydrates, starches, proteins, total phenols, flavonoids, and the enzymes pectin methylesterase and amylase in such a way that the pollens of 'Sheikhali', 'Fard', 'Zahedi' and 'Shahani' had more of the above substances than the other cultivars. The effects of pollens of these four cultivars on the characteristics of fruits formed from their fertilization with 'Piarom' date flower, showed that fruits formed with these pollens are superior to fruits obtained from pollens of other cultivars in terms of having secondary metabolites, sugars and enzymes. In particular the pollens of 'Fard' and 'Sheikhali' produced the best fruits in terms of having these substances. These results confirm the metaxenia effects of date pollen grains on fruit formation in the same year.

\section{Declarations}


The authors would like to thank Shiraz University for providing the laboratory equipment and financial support.

\section{Author contributions}

Ali Reza Shahsavar: Project administration, Methodology, Conceptualization, Validation, Writing-Original Draft, Writing-Review \& Editing, Resources, Supervision.

Asma Shahhosseini : Visualization, Investigation, Methodology, Formal analysis, Resources.

\section{Conflict of interest}

The authors declare that they have no known competing financial interests or personal relationships that could have appeared to influence the work reported in this paper.

\section{References}

1. Soliman, S. S. \& Al-Obeed, R. S. Investigations on the pollen morphology of some date palm males (Phoenix dactylifera L.) in Saudi Arabia. Australian Journal of Crop Science. 7(9), 1355-1360 (2013).

2. Al-khalifah, N. S. Metaxenia: Influence of pollen on the maternal tissue of fruits of two cultivars of date palm (Phoenix dactylifera L.). Bangladesh Journal of Botany. 35(2), 151-161 (2006).

3. Allaith, A. A. A. Antioxidant activity of Bahraini date palm (Phoenix dactylifera L.) fruit of various cultivars. International Journal of Food Science \& Technology.43(6), 1033-1040 (2008).

4. Yasin, B. R., El-Fawal, H. A. N. \& Mousa, S. A. Date (Phoenix dactylifera L.) polyphenolics and other bioactive compounds: A traditional Islamic remedy's potential in prevention of cell damage, cancer therapeutics and beyond. International Journal of Molecular Sciences. 16(12), 30075-30090 (2015).

5. Gu, L. W., Kelm, M. A., Hammerstone, J. F., Beecher, G., Holden, J., Haytowitz, D. \& Prior, R. L. Screening of foods containing proanthocyanidins and their structural characterization using LC-MS/MS and thiolytic degradation. Journal of Agricultural and Food Chemistry, 51(25), 7513-7521 (2003).

6. Izli, G. Total phenolics, antioxidant capacity, colour and drying characteristics of date fruit dried with different methods. Food Science and Technology. 0101-2061 (2016).

7. El-Sharnouby, G. A., Al-Eid, S. M. \& Al-Otaibi, M. M. Utilization of enzymes in the production of liquid sugar from dates. African Journal of Biochemistry Research. 3(3), 41-47 (2009).

8. Ait-Oubahou, A. \& Yahia, E.M. Postharvest Handling of Date, 10. Postharvest News and Information. pp. 67-74 (1999).

9. Amira, E. A., Saafi, E. B., Mechri, B., Lahouar, L., Issaoui, M., Hammami M. \& Achour, L. Effects of the ripening stage on phenolic profile, phytochemical composition and antioxidant activity of date palm fruit. Journal of Agriculturaland Food Chemistry.60, 10896-10902 (2012).

10. Besbes, S., Drira, L., Blecker, C., Deroanne, C. \& Attia, H. Adding value to hard date (Phoenix dactylifera L.): compositional, functional and sensory characteristics of date jam. Food Chemistry. 112 (2), 406Loading [MathJax]/jax/output/CommonHTML/jax.js 
411 (2009).

11. Kadam, V. B., Wadikar, M. S. \& Ahire, P. P. Bio-chemical analysis of leaves of some medicinal plants of Laling forest. Dhule District (M.S.), India. Journal Plant Archives. 8, 293-294 (2008).

12. Basu, S., Roychoudhury, A., Saha, P. P. \& Sengupta, D. N. Differential antioxidative responses of indica rice cultivars to drought stress. Plant Growth Regulation. 60, 51-59 (2010).

13. Ding, B., Shi, G., Xu, Y., Hu, J. \& Xu, Q. Physiological responses of Alternanthera philoxeroides (Mart.) Griseb leaves to cadmium stress. Journal of Environment and Pollution. 147, 800-803 (2007).

14. Chandrasekhar, J., Madhusudhan, M. \& Raghavarao, K. Extraction of anthocyanins from red cabbage and purification using adsorption . Food and Bioproducts Processing. 90(4), 615-623 (2012).

15. Quideau, S., Deffieux, D., Douat-Casassus, C. \& Pouysegu, L. Plant polyphenols: Chemical properties, biological activities and synthesis. Angewandte Chemie International Edition. 50(3), 586-621 (2011).

16. Pressman, E., Peet, M. M. \& Pharr, D. M. The effect of heat stress on tomato pollen characteristics is associated with changes in carbohydrate concentration in the developing anthers. Annals of Botany. 90(5), 631-636 (2002).

17. Bradford, M. A rapid and sensitive method for the quantitation of microgram quantities of protein utilizing the principle of protein-dye binding. Anal Biochemistry.72, 248-254 (1976).

18. Singleton, V. L., Orthofer, R. \& Lamuela-Raventos, R. M. Analysis of total phenols and other oxidation substrates and antioxidants by means of folin-ciocalteu reagent. Methods in Enzymology. 299, 152178 (1999).

19. Quettier-Deleu, C., Gressier, B., Vasseur, J., Dine, T., Brunet, C., Luyckx, M., Cazin, M., Cazin, J. C., Bailleul, F. \& Trotin, F. Phenolic compounds and antioxidant activities of buckweat hulls and flour. Journal Ethnopharmacol. 72, 35-42 (2000).

20. Ren, C. \& Kermode, A. R. An increase in pectin methyl esterase activity accompanies dormancy breakage and germination of yellow cedar seeds. Plant Physiology. 124, 231-242 (2000).

21. Johnson, R. Measuring amylase activity in cereal grains. Collby J. Res. Meth. 9, 11-13 (2007).

22. Lichtenthaler, H. K. Chlorophylls and carotenoids: pigments of photosynthetic biomembranes. Methods Enzymology. 148, 350-382 (1987).

23. 23. Zhang, C., Aldosari, S. A., Vidyasagar, P. S. P., Shukla, P. \& Nair, M. G. Determination of the variability of sugars in date fruit varieties. Journal Plant Crops. 43(1), 53-61 (2015).

24. Taira, S. Astringency in persimmon. In: Linskens, H. P., Jackson, J. F. (Eds.), Modern Methods of Plant Analysis, Fruit Analysis. Springer-Verlag, Berlin Heidelberg. 18, 97-110 (1996).

25. Velioglu, Y. S., Mazza, G., Gao, L. \& Oomah, B. D. Antioxidant activity and total phenolics in selected fruits, vegetables, and grain products. Journal of Agricultural and Food Chemistry. 46, 4113-4117 (1998).

26. Rabino, I., Mancinelli, A. L. \& Kuzmanoff, K. M. Photocontrol of anthocyanin synthesis. VI. Spectral sensitivity, irradiance dependence and reciprocity relationship. Plant Physiology. 59, 569-573 (1977). 
27. Zhou, H. W., Sonego, L., Khalchitski, A., Ben-Arie, R., Lers, A. \& Lurie, S. Cell wall enzymes and cell wall changes in 'Flavortop' nectarines: mRNA abundance, enzyme activity, and changes in pectic and neutral polymers during ripening and in woolly fruit. Journal of the American Society for Horticultural Science. 125(5), 630-637 (2000).

28. Kanner, J., Elmaleh, H., Reuveni, O. \& Ben-gera, I. Invertase (B-fructofuranosidase) activity in three date cultivars. Journal of Agricultural Food and Chemistry. 26, 1238-1240 (1978).

29. Gross, K. C. A rapid and sensitive spectrophotometric method for assaying polygalacturonase using 2- cyanoacetamide. Horticultural Science.17, 933-934 (1982).

30. Datta, R., Chamusco, K. C. \& Chourey, P. S. Starch biosynthesis during pollen maturation is associated with altered patterns of gene expression in maize. Plant Physiology. 130, 1645-1656 (2002).

31. Castro, A. J. \& Clement, C. Sucrose and starch catabolism in the anther of Lilium during its development: a comparative study among the anther wall, locular fluid and microspore/pollen fractions. Planta. 225, 1573-1582 (2007).

32. Nashilevitz, S., Melamed-Bessudo1, C., Aharoni, A., Kossmann, J., Wolf, S. \& Levy, A. A. The legwd mutant uncovers the role of starch phosphorylation in pollen development and germination in tomato. The Plant Journal. 57, 1-13 (2009).

33. Tai, H. R., Cane, J. H. \& Buchmann, S. L. What governs protein content of pollen: pollinator preferences, pollen-pistil interactions, or phylogeny?. Ecological Monographs. 70(4), 617-6 (2000).

34. Baker, H. G. \& Baker, I. Starchy and starchless pollen in the Onagraceae. Annals of the Missouri BotanicalGarden.748-754 (1982).

35. Stanley, R. G. Pollen chemistry and tube growth. In Pollen: development and physiology. 131-155 (1971).

36. Al-Shahib, W. \& Marshall R. J. The fruit of the date palm: its possible use as the best food for the future? International Journal of FoodSciences and Nutrition.54(4), 247-259 (2003).

37. Agarwal, S. \& Rao, A. V. Tomato lycopene and its role in human health and chronic diseases. Canadian Medical Association Journal. 163(6), 739-44 (2000).

38. Kumaran, A. \& Karunakaran, R. J. Antioxidant and free radical scavenging activity of an aqueous extract of Coleus aromaticus. Food Chemistry. 97, 109-114 (2006).

39. Liao, K. \& Yin, M. Individual and combined antioxidant effects of seven phenolic agents in human erythrocyte membrane ghosts and phosphatidylcholine liposome systems: importance of the partition coefficient. Journal of Agricultural Food Chemistry. 48, 2266-2270 (2000).

40. Woo, H. H., Jeong, B. R. \& Hawes, M. C. Flavonoids: From cell cycle to biotechnology. Biotechnology. 27, 365-374 (2005).

41. Parre, E. \& Geitmann, A. Pectin and the role of the physical properties of the cell wall in pollen tube growth of Solanum chacoense. Planta. 220, 582-592 (2005).

42. Pina, C., Pinto, F., Feijo, J. A. \& Becker, J. D. Gene family analysis of the Arabidopsis pollen transcriptome reveals biological implications for cell growth, division control, and gene expression Loading [MathJax]/jax/output/CommonHTML/jax.js 756 (2005). 
43. Holdaway-Clarke, T. L. \& Hepler, P. K. Control of pollen tube growth: role of ion gradients and fluxes. New Phytologist. 159, 539-563 (2003).

44. Bezerra, R. P., Borba, F. K. S. L., Moreira, K. A., Lima-Filho, J. L., Porto, A. L. F. \& Chaves, A. C. Extraction of amylase from fermentation broth in polyethylene glycol salt aqueous two-phase system. Biology and Technology. 49(4), 547-555 (2006).

45. Al-Turki, S., Shahba, M. A. \& Stushnoff, C. Diversity of antioxidant properties and phenolic content of date palm (Phoenix dactylifera L.) fruits as affected by cultivar and location. Journal of Food, Agriculture \& Environment.8, 253-260 (2010).

46. Hammouda, H., Cherif, J. K., Trabelsi-Ayadi, M., Baron, A. \& Guyot, S. Detailed polyphenol and tannin composition and its variability in Tunisian dates (Phoenix dactylifera L.) at different maturity stages. Journal of Agricultural and Food Chemistry. 61, 3252-3263 (2013).

47. Amiot, J. M., Tacchini, M., Aubert, S.Y. \& Oleszek, W. Influence on cultivars, maturity stage and storage conditions on phenolic composition and enzymatic browning of pear fruit. Journal of Agricultural and Food Chemistry.43, 1132-1137 (1995).

48. Myhara, R. M., Karkala J. \& Taylor, M. S. The composition of maturing Omani dates. Journal of the Science of Food and Agriculture. 79, 1345-1350 (1999).

49. Ibrahim, A. I., Emara, H. A., Nower, A. A. \& Atfi, M. S. In vitro study on germination of date palm pollen grains and its impact on fruit quality. Life Science Journal. 11(10), 1291-1300 (2014).

50. Farag, K. M., Elsabagh, A. S. \& ElAshry, H. A. Fruit characteristics of 'Zaghloul' date palm in relation to metaxenic influences of used pollinator. American-Eurasian Journal of Agricultural \& Environmental Sciences. 12(7), 842-855 (2012a).

51. Al-Redhaiman, A. Modified atmosphere improves storage ability, controls decay and maintains quality and antioxidant contents of Barhi date fruits. Journal of Food, Agriculture \& Environment. 2, 25-32 (2004).

52. Wang, Z., Zheng, P. \& Meng, J., Xi, Z. Effect of exogenous 24-epibrassinolide on chlorophyll fluorescence, leaf surface morphology and cellular ultrastructure of grape seedlings (Vitis vinifera L.) under water stress. ActaPhysiologiae Plantarum. 37(1), 1729 (2015).

53. Farag, K. M., Elsabagh, A. S. \& ElAshry, H. A. Phytohormonal changes in fruits of 'Zaghloul' date palm in relation to metaxenic influences of used pollinators. American-Eurasian Journal of Agricultural \& EnvironmentalSciences,12(7), 862-871 (2012b).

54. Hong, Y. J., Tomas-Barberan, F. A., Kader, A. A. \& Mitchell, A. E. The flavonoid glycosides and procyanidin composition of Deglet Noor dates (Phoenix dactylifera L.). Journal of Agricultural and Food Chemistry.54, 2405-2411 (2006).

55. Prochazkova, D., Sairam, R. K., Srivastava, G. C. \& Singh, D. V. Oxidative stress and antioxidant activity as the basis of senescence in maize leaves. Plant Science. 161, 765-771 (2001).

56. Boudries, H., Kefalas, P. \& Hornero-Mendez, D. Carotenoid composition of Algerian date varieties (Phoenix dactylifera L.) at different edible maturation stages. Food Chemistry. 101(4), 1372-1377 
57. Garnczarska, M., Bednarski, W. \& Morkunas, I. Re-aeration-induced oxidative stress and antioxidative defenses in hypoxically pretreated lupine roots. Journal of Plant Physiology. 161, 415- 422 (2004).

58. Candan, N. \& Tarhan, L. Change in chlorophyll-carotenoid contents, antioxidant enzyme activities and lipid peroxidation levels in Zn-stressed Mentha pulegium. Turkish Journal of Chemistry. 27, 2130 (2003).

59. Cabrita, L., Fossen, T. \& Andersen, O. M. Colour and stability of the six common anthocyanidin 3glucosides in aqueous solutions. Food Chemistry. 68, 101-107 (2000).

60. Kulkarni, S. G., Vijayanand, P., Aksha, M., Reena, P. \& Ramana, K. V. R. Effect of dehydration on the quality and storage stability of immature dates (Phoenix dactylifera L.). LWT-Food Science Technology. 41, 278- 283 (2008).

61. Hasnaoui, A., Elhoumaizi, M. A., Hakkou, A., Wathelet, B. \& Sindic, M. Physico-chemical characterization, classification and quality evaluation of date palm fruits of some Moroccan cultivars. Journal of Scientific Research. 1, 139-149 (2011).

62. El-Hamady, M., Hamdia, M., Ayaad, M., Salama, M. E. \& Omar, A. K. H. Metaxenic effects as related to hormonal changes during date palm (Phoenix dactylifera L.) fruit growth and development. Acta Horticulturae. 882, 155-164 (2010).

63. Mustafa, A. B., Harper, D. B. \& Johnston, D. E. Biochemical changes during ripening of some Sudanese date varieties. Journal of the Science of Food and Agriculture. 37(1), 43-53 (1986).

64. Brummell, D. A. \& Harpster, M. H. Cell wall metabolism in fruit softening and quality and its manipulation in transgenic plants. Plant Molecular Biology.47, 311-339 (2001).

65. Awad, M. A., Al-Qurashia, A. D. \& Mohamed, S. A. Antioxidant capacity, antioxidant compounds and antioxidant enzyme activities in five date cultivars during development and ripening. Scientia Horticulturae. 129, 688-693 (2011).

66. Giovannoni, J. Genetic regulation of fruit development and ripening. The Plant Cell. 20, 1-11 (2004).

67. Abd-Al-Wahid, A. H. \& Abid, A. M. Changes in enzymatic activities of invertase and cellulase and some chemical characteristics during growth and ripening of 'Hillawi' date palm fruits. Journal Basrah Date Palm Research. 3, 53-58 (2004).

68. Rastegar, S., Rahemi, M., Baghizadeh, A. \& Gholami, M. Enzyme activity and biochemical changes of three date palm cultivars with different softening pattern during ripening. Food Chemistry. 134, 1279-1286 (2012).

\section{Tables}

Table 1 The pollen grain ingredients of eight pollinator cultivars of date palm 


\begin{tabular}{|c|c|c|c|c|c|c|c|}
\hline Cultivars & $\begin{array}{l}\text { Carbohydrate } \\
\text { (\%) }\end{array}$ & $\begin{array}{l}\text { Protein } \\
\text { (\%) }\end{array}$ & $\begin{array}{l}\text { Starch } \\
(\%)\end{array}$ & $\begin{array}{l}\text { Total } \\
\text { phenol } \\
(\mathrm{mg} \\
\mathrm{GAE} / \mathrm{g})\end{array}$ & $\begin{array}{l}\text { Flavonoids } \\
\text { (mg QE/g) }\end{array}$ & $\begin{array}{l}\text { Pectin } \\
\text { methyl } \\
\text { esterase } \\
\text { (IU/g. FW) }\end{array}$ & $\begin{array}{l}\text { Amylase } \\
(\mathrm{IU} / \mathrm{mg} . \mathrm{FW})\end{array}$ \\
\hline 'Shahani' & $13.33 \mathrm{a}$ & $\begin{array}{l}30.22 \\
a b\end{array}$ & $\begin{array}{l}9.01 \\
a b\end{array}$ & $36.11 \mathrm{c}$ & $9.86 \mathrm{a}$ & $1.41 \mathrm{c}$ & $80.83 \mathrm{~b}$ \\
\hline 'Kabkab' & $11.80 \mathrm{~b} \mathrm{c}$ & $\begin{array}{l}29.47 \\
b\end{array}$ & $\begin{array}{l}8.33 \\
\mathrm{de}\end{array}$ & $17.40 \mathrm{f}$ & $5.46 \mathrm{~d}$ & $0.61 \mathrm{e}$ & $62.86 \mathrm{~d}$ \\
\hline 'Zahedi' & $13.19 \mathrm{a}$ & $\begin{array}{l}31.60 \\
a\end{array}$ & $\begin{array}{l}8.83 \\
\text { bc }\end{array}$ & $\begin{array}{l}45.83 \\
b\end{array}$ & $9.60 \mathrm{a}$ & $1.27 \mathrm{c}$ & $84.40 \mathrm{a}$ \\
\hline 'Beraem' & $11.63 \mathrm{c}$ & $\begin{array}{l}30.13 \\
\mathrm{ab}\end{array}$ & $8.20 \mathrm{e}$ & $\begin{array}{l}19.61 \\
\text { ef }\end{array}$ & $4.18 \mathrm{e}$ & $0.54 \mathrm{e}$ & $66.53 c$ \\
\hline 'Faryab' & $12.61 \mathrm{abc}$ & $\begin{array}{l}29.79 \\
a b\end{array}$ & $\begin{array}{l}8.50 \\
\text { de }\end{array}$ & $22.19 \mathrm{e}$ & $6.06 \mathrm{~d}$ & $0.85 \mathrm{~d}$ & $61.16 \mathrm{~d}$ \\
\hline 'Sheikhali' & $13.04 \mathrm{a}$ & $\begin{array}{l}31.10 \\
a b\end{array}$ & $\begin{array}{l}8.82 \\
\text { bc }\end{array}$ & $\begin{array}{l}50.77 \\
a\end{array}$ & $8.84 \mathrm{~b}$ & $1.94 \mathrm{ab}$ & $81.40 a b$ \\
\hline 'Fard' & $13.86 \mathrm{a}$ & $\begin{array}{l}30.74 \\
a b\end{array}$ & $9.29 \mathrm{a}$ & $\begin{array}{l}49.68 \\
a\end{array}$ & $9.29 a b$ & $1.76 \mathrm{~b}$ & $80.80 \mathrm{~b}$ \\
\hline 'Jarvis' & $12.90 \mathrm{ab}$ & $\begin{array}{l}30.86 \\
a b\end{array}$ & $\begin{array}{l}8.60 \\
\mathrm{~cd}\end{array}$ & 28.40 & $8.07 c$ & $2.10 \mathrm{a}$ & $67.73 \mathrm{c}$ \\
\hline
\end{tabular}

Different letters within columns indicate significant differences according to Duncan's multiple range test $(p<0.05)$.

Table 2 Total phenol content of 'Piarom' date fruit in kimri, khalal, rutab and tamar stages after pollination with eight pollinating cultivars 


\begin{tabular}{|c|c|c|c|c|}
\hline Cultivars & $\begin{array}{l}\text { Kimri } \\
(\mathrm{mg} / 100 \mathrm{~g})\end{array}$ & $\begin{array}{l}\text { Khalal } \\
(\mathrm{mg} / 100 \mathrm{~g})\end{array}$ & $\begin{array}{l}\text { Rutab } \\
(\mathrm{mg} / 100 \mathrm{~g})\end{array}$ & $\begin{array}{l}\text { Tamar } \\
(\mathrm{mg} / 100 \mathrm{~g})\end{array}$ \\
\hline 'Shahani' & $152.82 \mathrm{a}$ & $91.74 \mathrm{a}$ & $43.90 \mathrm{a}$ & $22.47 \mathrm{a}$ \\
\hline ‘Kabkab’ & $149.53 \mathrm{~d}$ & $89.28 \mathrm{c}$ & $40.20 \mathrm{~d}$ & $20.47 b$ \\
\hline 'Zahedi' & $151.91 \mathrm{~b}$ & $90.88 \mathrm{~b}$ & 43.04 bc & $21.72 a b$ \\
\hline ‘Beraem’ & $150.44 \mathrm{c}$ & $89.42 \mathrm{c}$ & $40.47 d$ & $20.50 \mathrm{~b}$ \\
\hline 'Faryab' & $151.45 b$ & $90.41 \mathrm{~b}$ & $42.56 \mathrm{c}$ & $21.24 a b$ \\
\hline 'Sheikhali' & $151.98 b$ & $91.70 \mathrm{a}$ & $43.60 \mathrm{ab}$ & $21.94 a b$ \\
\hline 'Fard' & $151.78 b$ & $90.75 \mathrm{~b}$ & $42.84 \mathrm{bc}$ & $21.53 \mathrm{ab}$ \\
\hline 'Jarvis' & $152.89 a$ & 91.92 a & $44.03 \mathrm{a}$ & $22.63 \mathrm{a}$ \\
\hline
\end{tabular}

Different letters within columns indicate significant differences according to Duncan's multiple range test $(p<0.05)$.

Table 3 The amount of soluble tannin in the fruit of 'Piarom' dates in the kimri, khalal, rutab and tamar stages after pollination with eight pollinating cultivars 


\begin{tabular}{|c|c|c|c|c|}
\hline Cultivars & $\begin{array}{l}\text { Kimri } \\
(\mathrm{mg} / \mathrm{g})\end{array}$ & $\begin{array}{l}\text { Khalal } \\
(\mathrm{mg} / \mathrm{g})\end{array}$ & $\begin{array}{l}\text { Rutab } \\
(\mathrm{mg} / \mathrm{g})\end{array}$ & $\begin{array}{l}\text { Tamar } \\
(\mathrm{mg} / \mathrm{g})\end{array}$ \\
\hline 'Shahani' & $11.66 \mathrm{bc}$ & 10.76 bc & $3.54 \mathrm{~b}$ & $3.55 b$ \\
\hline 'Kabkab' & $12.17 \mathrm{a}$ & $11.42 \mathrm{a}$ & $4.22 \mathrm{a}$ & $4.13 \mathrm{a}$ \\
\hline 'Zahedi' & $11.62 \mathrm{c}$ & 10.72 bc & $3.44 \mathrm{~b}$ & $2.86 \mathrm{c}$ \\
\hline ‘Beraem’ & $12.06 \mathrm{ab}$ & $11.40 \mathrm{a}$ & $4.18 \mathrm{a}$ & $4.12 \mathrm{a}$ \\
\hline 'Faryab' & $12.04 \mathrm{ab}$ & $11.28 \mathrm{a}$ & $4.09 a$ & $3.61 \mathrm{~b}$ \\
\hline 'Sheikhali' & $11.47 \mathrm{c}$ & $10.65 \mathrm{bc}$ & $3.4 \mathrm{~b}$ & $2.84 \mathrm{C}$ \\
\hline 'Fard' & $11.39 \mathrm{c}$ & $10.59 \mathrm{c}$ & $3.35 b$ & $2.75 \mathrm{c}$ \\
\hline 'Jarvis' & $12.20 \mathrm{a}$ & $11.09 a b$ & $4.06 \mathrm{a}$ & $3.59 \mathrm{~b}$ \\
\hline
\end{tabular}

Different letters within columns indicate significant differences according to Duncan's multiple range test $(p<0.05)$.

Table 4 Chlorophyll a content of 'Piarom' date fruit in kimri, khalal, rutab and tamar stages after pollination with eight pollinating cultivars 


\begin{tabular}{|c|c|c|c|c|}
\hline Cultivars & $\begin{array}{l}\text { Kimri } \\
(\mathrm{mg} / 100 \mathrm{~g})\end{array}$ & $\begin{array}{l}\text { Khalal } \\
(\mathrm{mg} / 100 \mathrm{~g})\end{array}$ & $\begin{array}{l}\text { Rutab } \\
\text { (mg/100g) }\end{array}$ & $\begin{array}{l}\text { Tamar } \\
(\mathrm{mg} / 100 \mathrm{~g})\end{array}$ \\
\hline 'Shahani' & $1.45 \mathrm{a}$ & $0.75 \mathrm{~d}$ & $0.27 \mathrm{~cd}$ & $0.25 \mathrm{~cd}$ \\
\hline ‘Kabkab’ & $1.27 \mathrm{c}$ & $0.87 a b$ & $0.37 \mathrm{a}$ & $0.35 a$ \\
\hline 'Zahedi' & $1.37 \mathrm{~b}$ & $0.69 \mathrm{e}$ & 0.26 cde & $0.23 \mathrm{de}$ \\
\hline ‘Beraem’ & $1.04 \mathrm{~d}$ & $0.85 b c$ & $0.35 a b$ & $0.33 a b$ \\
\hline 'Faryab' & $1.07 \mathrm{~d}$ & $0.82 \mathrm{c}$ & $0.31 b c$ & $0.28 \mathrm{c}$ \\
\hline 'Sheikhali' & $1.35 \mathrm{~b}$ & $0.68 \mathrm{e}$ & $0.23 \mathrm{de}$ & $0.21 \mathrm{de}$ \\
\hline 'Fard' & $1.23 \mathrm{c}$ & $0.67 \mathrm{e}$ & $0.21 \mathrm{e}$ & $0.20 \mathrm{e}$ \\
\hline 'Jarvis' & $1.47 \mathrm{a}$ & $0.90 \mathrm{a}$ & $0.37 a$ & $0.35 a$ \\
\hline
\end{tabular}

Different letters within columns indicate significant differences according to Duncan's multiple range test $(p<0.05)$.

Table 5 Chlorophyll b content of 'Piarom' date fruit in kimri, khalal, rutab and tamar stages after pollination with eight pollinating cultivars 


\begin{tabular}{|c|c|c|c|c|}
\hline Cultivars & $\begin{array}{l}\text { Kimri } \\
(\mathrm{mg} / 100 \mathrm{~g})\end{array}$ & $\begin{array}{l}\text { Khalal } \\
(\mathrm{mg} / 100 \mathrm{~g})\end{array}$ & $\begin{array}{l}\text { Rutab } \\
\text { (mg/100g) }\end{array}$ & $\begin{array}{l}\text { Tamar } \\
(\mathrm{mg} / 100 \mathrm{~g})\end{array}$ \\
\hline 'Shahani' & $0.34 \mathrm{a}$ & $0.30 a b$ & $0.25 a b$ & $0.23 a b$ \\
\hline ‘Kabkab’ & $0.32 \mathrm{ab}$ & $0.32 a b$ & $0.27 \mathrm{a}$ & $0.25 \mathrm{a}$ \\
\hline 'Zahedi' & $0.33 a b$ & $0.30 a b$ & $0.25 a b$ & $0.23 a b$ \\
\hline ‘Beraem’ & $0.31 \mathrm{~b}$ & $0.31 \mathrm{ab}$ & $0.27 a$ & $0.24 a b$ \\
\hline 'Faryab' & $0.31 \mathrm{~b}$ & $0.31 \mathrm{ab}$ & $0.26 a b$ & $0.24 a b$ \\
\hline 'Sheikhali' & $0.33 a b$ & $0.28 \mathrm{~b}$ & $0.23 \mathrm{~b}$ & $0.21 \mathrm{~b}$ \\
\hline 'Fard' & $0.32 \mathrm{ab}$ & $0.28 \mathrm{~b}$ & $0.23 \mathrm{~b}$ & $0.21 \mathrm{~b}$ \\
\hline 'Jarvis' & $0.34 \mathrm{a}$ & $0.33 a$ & $0.28 a$ & $0.25 a$ \\
\hline
\end{tabular}

Different letters within columns indicate significant differences according to Duncan's multiple range test $(p<0.05)$.

Table 6 The amount of carotenoids of 'Piarom' date fruit in kimri, khalal, rutab and tamar stages after pollination of eight pollinating cultivars 


\begin{tabular}{|lllll|}
\hline Cultivars & $\begin{array}{l}\text { Kimri } \\
(\mathrm{mg} / 100 \mathrm{~g})\end{array}$ & $\begin{array}{l}\text { Khalal } \\
(\mathrm{mg} / 100 \mathrm{~g})\end{array}$ & $\begin{array}{l}\text { Rutab } \\
(\mathrm{mg} / 100 \mathrm{~g})\end{array}$ & $\begin{array}{l}\text { Tamar } \\
(\mathrm{mg} / 100 \mathrm{~g})\end{array}$ \\
\hline 'Shahani' & $0.41 \mathrm{ab}$ & $0.73 \mathrm{bc}$ & $0.11 \mathrm{bcd}$ & $0.10 \mathrm{bc}$ \\
\hline 'Kabkab' & $0.39 \mathrm{~b}$ & $0.71 \mathrm{c}$ & $0.09 \mathrm{~d}$ & $0.07 \mathrm{~d}$ \\
\hline 'Zahedi' & $0.41 \mathrm{ab}$ & $0.73 \mathrm{bc}$ & $0.13 \mathrm{ab}$ & $0.10 \mathrm{bc}$ \\
\hline 'Beraem' & $0.39 \mathrm{~b}$ & $0.71 \mathrm{c}$ & $0.10 \mathrm{~cd}$ & $0.08 \mathrm{~d}$ \\
\hline 'Faryab' & $0.40 \mathrm{~b}$ & $0.72 \mathrm{c}$ & $0.11 \mathrm{bcd}$ & $0.09 \mathrm{~cd}$ \\
& & & & \\
\hline 'Sheikhali' & $0.42 \mathrm{a}$ & $0.75 \mathrm{ab}$ & $0.14 \mathrm{a}$ & $0.11 \mathrm{ab}$ \\
\hline 'Fard' & $0.42 \mathrm{a}$ & $0.76 \mathrm{a}$ & $0.15 \mathrm{a}$ & $0.12 \mathrm{a}$ \\
& & & & \\
'Jarvis' & $0.41 \mathrm{ab}$ & $0.72 \mathrm{c}$ & $0.11 \mathrm{bcd}$ & $0.09 \mathrm{~cd}$ \\
\hline
\end{tabular}

Different letters within columns indicate significant differences according to Duncan's multiple range test $(p<0.05)$.

Table 7 The amount of anthocyanin in 'Piarom' date fruit in kimri, khalal, rutab and tamar stages after pollination with eight pollinating cultivars 


\begin{tabular}{|lllll|}
\hline Cultivars & $\begin{array}{l}\text { Kimri } \\
(\mathrm{mg} / 100 \mathrm{~g})\end{array}$ & $\begin{array}{l}\text { Khalal } \\
(\mathrm{mg} / 100 \mathrm{~g})\end{array}$ & $\begin{array}{l}\text { Rutab } \\
(\mathrm{mg} / 100 \mathrm{~g})\end{array}$ & $\begin{array}{l}\text { Tamar } \\
(\mathrm{mg} / 100 \mathrm{~g})\end{array}$ \\
\hline 'Shahani' & $0.081 \mathrm{a}$ & $0.084 \mathrm{a}$ & $0.066 \mathrm{a}$ & $0.037 \mathrm{a}$ \\
\hline 'Kabkab' & $0.061 \mathrm{~b}$ & $0.062 \mathrm{~b}$ & $0.045 \mathrm{~b}$ & $0.022 \mathrm{~b}$ \\
\hline 'Zahedi' & $0.080 \mathrm{a}$ & $0.084 \mathrm{a}$ & $0.065 \mathrm{a}$ & $0.037 \mathrm{a}$ \\
\hline 'Beraem' & $0.063 \mathrm{~b}$ & $0.065 \mathrm{~b}$ & $0.045 \mathrm{~b}$ & $0.022 \mathrm{~b}$ \\
\hline 'Faryab' & $0.075 \mathrm{a}$ & $0.083 \mathrm{a}$ & $0.063 \mathrm{a}$ & $0.036 \mathrm{a}$ \\
& & & & \\
\hline 'Sheikhali' & A0.08 1 & $0.084 \mathrm{a}$ & $0.067 \mathrm{a}$ & $0.037 \mathrm{a}$ \\
& & & & \\
\hline
\end{tabular}

Different letters within columns indicate significant differences according to Duncan's multiple range test $(p<0.05)$.

Table 8 The amount of glucose, fructose and sucrose sugars in 'Piarom' date fruit (tamar stage) after pollination with eight pollinating cultivars 


\begin{tabular}{|llll|}
\hline Cultivars & $\begin{array}{c}\text { Glucose } \\
(\mathrm{g} / 100 \mathrm{~g})\end{array}$ & $\begin{array}{c}\text { Fructose } \\
(\mathrm{g} / 100 \mathrm{~g})\end{array}$ & $\begin{array}{l}\text { Sucrose } \\
(\mathrm{g} / 100 \mathrm{~g})\end{array}$ \\
\hline 'Shahani' & $32.75 \mathrm{c}$ & $22.67 \mathrm{~b}$ & $0.79 \mathrm{~d}$ \\
\hline 'Kabkab' & $29.09 \mathrm{e}$ & $20.07 \mathrm{~d}$ & $0.57 \mathrm{e}$ \\
\hline 'Zahedi' & $35.02 \mathrm{a}$ & $23.13 \mathrm{a} \mathrm{b}$ & $1.23 \mathrm{c}$ \\
\hline 'Beraem' & $29.44 \mathrm{e}$ & $20.39 \mathrm{~d}$ & $0.65 \mathrm{de}$ \\
\hline 'Faryab' & $30.35 \mathrm{~d}$ & $21.47 \mathrm{c}$ & $0.72 \mathrm{~d}$ \\
& & & \\
\hline 'Sheikhali' & $35.47 \mathrm{a}$ & $23.57 \mathrm{a}$ & $1.61 \mathrm{~b}$ \\
& & & \\
\hline 'Fard' & $35.28 \mathrm{a}$ & $23.38 \mathrm{a}$ & $1.27 \mathrm{c}$ \\
& & & \\
\hline 'Jarvis' & $34.24 \mathrm{~b}$ & $22.71 \mathrm{~b}$ & $1.90 \mathrm{a}$ \\
\hline
\end{tabular}

Different letters within columns indicate significant differences according to Duncan's multiple range test $(p<0.05)$.

Table 9 Polygalacturonase enzyme activity of 'Piarom' date fruit in kimri, khalal, rutab and tamar stages after pollination with eight pollinating cultivars 


\begin{tabular}{|lllll|}
\hline Cultivars & $\begin{array}{l}\text { Kimri } \\
\text { (IU/g.FW) }\end{array}$ & $\begin{array}{l}\text { Khalal } \\
(\mathrm{IU} / \mathrm{g} . \mathrm{FW})\end{array}$ & $\begin{array}{l}\text { Rutab } \\
(\mathrm{IU} / \mathrm{g} . \mathrm{FW})\end{array}$ & $\begin{array}{l}\text { Tamar } \\
(\mathrm{IU} / \mathrm{g} . \mathrm{FW})\end{array}$ \\
\hline 'Shahani' & $2.39 \mathrm{a}$ & $2.48 \mathrm{~b}$ & $6.49 \mathrm{c}$ & $7.10 \mathrm{c}$ \\
\hline 'Kabkab' & $2 \mathrm{~d}$ & $2.08 \mathrm{~d}$ & $3.84 \mathrm{f}$ & $4.04 \mathrm{f}$ \\
\hline 'Zahedi' & $2.40 \mathrm{a}$ & $2.49 \mathrm{~b}$ & $6.98 \mathrm{~b}$ & $7.21 \mathrm{c}$ \\
\hline 'Beraem' & $2.02 \mathrm{~d}$ & $2.09 \mathrm{~d}$ & $3.87 \mathrm{f}$ & $4.09 \mathrm{f}$ \\
\hline 'Faryab' & $2.10 \mathrm{c}$ & $2.21 \mathrm{c}$ & $4.67 \mathrm{e}$ & $5.20 \mathrm{e}$ \\
& & & & \\
\hline 'Sheikhali' & $2.43 \mathrm{a}$ & $2.49 \mathrm{~b}$ & $7.05 \mathrm{~b}$ & $8.09 \mathrm{~b}$ \\
& & & & \\
\hline 'Fard' & $2.45 \mathrm{a}$ & $2.54 \mathrm{a}$ & $8.20 \mathrm{a}$ & $8.77 \mathrm{a}$ \\
& & & & \\
\hline 'Jarvis' & $2.20 \mathrm{~b}$ & $2.27 \mathrm{c}$ & $5.92 \mathrm{~d}$ & $6.26 \mathrm{~d}$ \\
\hline
\end{tabular}

Different letters within columns indicate significant differences according to Duncan's multiple range test $(p<0.05)$.

Table 10 Cellulose enzyme activity of 'Piarom' date fruit in kimri, khalal, rutab and tamar stages after pollination with eight pollinating cultivars 


\begin{tabular}{|c|c|c|c|c|}
\hline Cultivars & $\begin{array}{l}\text { Kimri } \\
\left(\mathrm{IU} / \mathrm{g} . \mathrm{FW} \times 10^{-3}\right)\end{array}$ & $\begin{array}{l}\text { Khalal } \\
\left(\mathrm{IU} / \mathrm{g} . \mathrm{FW} \times 10^{-3}\right)\end{array}$ & $\begin{array}{l}\text { Rutab } \\
\left(\mathrm{IU} / \mathrm{g} . \mathrm{FW} \times 10^{-3}\right)\end{array}$ & $\begin{array}{l}\text { Tamar } \\
\left(\mathrm{IU} / \mathrm{g} . \mathrm{FW} \times 10^{-3}\right)\end{array}$ \\
\hline 'Shahani’ & $209.75 a b$ & $497.75 \mathrm{~d}$ & $521 d$ & $582 \mathrm{bc}$ \\
\hline 'Kabkab’ & $195.75 a b$ & $424.50 \mathrm{e}$ & $435.75 \mathrm{fg}$ & $495.25 \mathrm{e}$ \\
\hline 'Zahedi' & $220.25 \mathrm{a}$ & $660 \mathrm{~b}$ & $682.75 \mathrm{~b}$ & 830.75 a \\
\hline ‘Beraem’ & $181.75 b$ & $380.50 \mathrm{f}$ & $407.50 \mathrm{~g}$ & $440.75 \mathrm{f}$ \\
\hline 'Faryab' & $204 a b$ & $433.50 \mathrm{e}$ & 452.50 ef & $518.50 \mathrm{de}$ \\
\hline 'Sheikhali' & $213.25 a b$ & $549.75 \mathrm{c}$ & $569 c$ & $607 \mathrm{~b}$ \\
\hline 'Fard' & $228.50 \mathrm{a}$ & 778 a & $791.50 \mathrm{a}$ & $866 a$ \\
\hline 'Jarvis' & $206 \mathrm{ab}$ & $470 \mathrm{~d}$ & $489.75 \mathrm{de}$ & $554.75 \mathrm{~cd}$ \\
\hline
\end{tabular}

Different letters within columns indicate significant differences according to Duncan's multiple range test $(p<0.05)$.

Table 11 Invertase enzyme activity of 'Piarom' date fruit in kimri, khalal, rutab and tamar stages after pollination with eight pollinating cultivars 


\begin{tabular}{|c|c|c|c|c|}
\hline Cultivars & $\begin{array}{l}\text { Kimri } \\
\text { (IU/g.FW) }\end{array}$ & $\begin{array}{l}\text { Khalal } \\
\text { (IU/g.FW) }\end{array}$ & $\begin{array}{l}\text { Rutab } \\
\text { (IU/g.FW) }\end{array}$ & $\begin{array}{l}\text { Tamar } \\
\text { (IU/g.FW) }\end{array}$ \\
\hline 'Shahani' & $0.60 \mathrm{~d}$ & $0.92 e$ & $0.83 c$ & $0.68 d$ \\
\hline 'Kabkab’ & $0.28 \mathrm{f}$ & $0.37 \mathrm{~g}$ & $0.27 \mathrm{e}$ & $0.26 \mathrm{e}$ \\
\hline 'Zahedi' & $1.16 \mathrm{~b}$ & $1.55 \mathrm{c}$ & $1.17 \mathrm{~b}$ & $1.16 \mathrm{~b}$ \\
\hline 'Beraem' & 0.31 ef & $0.44 \mathrm{~g}$ & $0.33 \mathrm{de}$ & $0.28 \mathrm{e}$ \\
\hline 'Faryab' & $0.42 \mathrm{e}$ & $0.72 \mathrm{f}$ & $0.41 \mathrm{~d}$ & $0.36 \mathrm{e}$ \\
\hline 'Sheikhali' & $1036 \mathrm{a}$ & $1.80 \mathrm{a}$ & $1.60 \mathrm{a}$ & $1.35 \mathrm{a}$ \\
\hline 'Fard' & $1028 \mathrm{a}$ & $1.67 \mathrm{~b}$ & $1.49 a$ & $1.28 \mathrm{ab}$ \\
\hline 'Jarvis' & $0.84 \mathrm{c}$ & $1.06 \mathrm{~d}$ & $0.94 \mathrm{c}$ & $0.83 \mathrm{c}$ \\
\hline
\end{tabular}

Different letters within columns indicate significant differences according to Duncan's multiple range test $(p<0.05)$. 